\title{
Caracterização das alterações de linguagem em crianças com histórico de intoxicação por chumbo ${ }^{* * * *}$
}

\author{
Characterization of language disorders in children with lead \\ poisoning
}

\author{
Dáphine Luciana Costa Gahyva* \\ Patrícia de Abreu Pinheiro Crenitte** \\ Magali de Lourdes Caldana*** \\ Simone Rocha de Vasconcellos Hage**
}

*Fonoaudióloga. Mestre em

Fonoaudiologia pela Faculdade de Odontologia de Bauru da Universidade de São Paulo. Endereço para correspondência: QRSW 07, Bloco B9, Apto. 106 - Setor Sudoeste - Brasília DF - CEP 70675-729

(daphiusp@yahoo.com)

**Fonoaudióloga. Doutora em Neurociências pela Universidade de Campinas. Professora do Curso de Fonoaudiologia da Faculdade de Odontologia de Bauru da Universidade de São Paulo.

***Fonoaudióloga. Doutora em Lingüística pela Universidade Estadual Paulista de Araraquara. Professora do Curso de

Fonoaudiologia da Faculdade de Odontologia de Bauru da Universidade de São Paulo.

****Trabalho Realizado na Faculdade de Odontologia de Bauru -

Universidade de São Paulo -

Departamento de Fonoaudiologia.

Artigo Original de Pesquisa

Artigo Submetido a Avaliação por Pares

Conflito de Interesse: não

\begin{abstract}
Background: lead poisoning can have a negative impact on the neuropsychological functions, including language, due to the damage it causes to the development of the Central Nervous System. Aim: to verify the occurrence of language disorders in children who suffered from led poisoning and to verify the correlation between the lead concentration level in the blood and the language disorders presented by the children. Method: language evaluation of 20 preschoolers, with lead concentration level in the blood above $10 \mu \mathrm{g} / \mathrm{dl}$. Results: 13 children presented language impairment involving only phonology or more than one language subsystem. The statistical analysis indicated that no correlation exists between the severity of the language impairment and the concentration levels of lead. Conclusion: the number of children with language impairment indicates lead poisoning as a risk factor for the present alterations, even though other risk factors for language disorders were found and the absence of correlation between the investigated variables.
\end{abstract}

Key Words: Lead Poisoning; Language Development Disorders; Cognition.

\section{Resumo}

Tema: a intoxicação por chumbo pode causar deficiências neuropsicológicas, que incluem a linguagem, devido aos danos provocados no desenvolvimento do SNC. Objetivo: verificar a ocorrência de alterações de linguagem em crianças com histórico de intoxicação por chumbo e a correlação entre o índice de chumbo sangüíneo e as alterações de linguagem apresentadas pelas crianças. Método: avaliação da linguagem de 20 crianças em idade pré-escolar, com índice de chumbo sangüíneo acima de $10 \mu \mathrm{g} / \mathrm{dl}$. Resultados: 13 crianças apresentaram distúrbio de linguagem envolvendo somente a Fonologia ou mais de um subsistema lingüístico. A análise estatistica revelou não existir correlação entre a gravidade das alterações e os índices de chumbo apresentado. Conclusão: a ocorrência de crianças com distúrbio de linguagem aponta a contaminação por chumbo como um fator de risco para as alterações apresentadas, mesmo tendo sido encontrados outros fatores que levem à defasagem no desenvolvimento da linguagem e ausência de correlação entre as referidas variavéis.

Palavras-Chave: Intoxicação por Chumbo; Transtornos do Desenvolvimento da Linguagem; Cognição. 


\section{Introduction}

The specialized literature points to strong evidences of neuropsychological disorders caused by lead exposure, including deficits of attention, concentration, memory, intelligence, learning, language, psychomotor behavior, interpersonal behavior, besides growth delay and endocrinological effects from mild to severe degrees, especially in cases where the lead concentration is above the limit established as tolerable, up to $10 \mathrm{~g} / \mathrm{dl}$ (1-3).

Despite several studies reveal that elevated lead levels are able to influence the development of distinct cognitive skills, having some finding, also, association between lead concentration and the performance in the evaluated cognitive abilities, the results still are incongruous (4-6). Some authors suggest that even lower lead levels than the accepted by the World Health Organization present risk for disorders in the skills mentioned above, indicating that a security margin does not exist for lead exposure (3, 7-9). On the other hand, certain studies do not find correlation between the blood lead level and the neuropsychological dysfunctions presented by contaminated children, evidencing that genetic and environmental factors may aggravate the hindering effects of the lead in the neural development, making some children more vulnerable to the neurotoxic effects of the metal, or yet, despite having a significant influence in children's development, other environmental factors may be even stronger (10-12).

Considering that pre-school children are a very susceptible group to the lead effects, this research aimed to verify language disorders in children with lead poisoning background, and to verify the existence of a correlation between the blood lead level and the language disorders presented by children.

\section{Method}

This research was approved by the Research Ethics Committee (CEP) of São Paulo University, Bauru campus / FOB-USP (process no: 040/2003) and all parents of subjects involved consented to have the results published according resolution 196/96.

An environmental accident involving a battery company in a certain neighborhood of Bauru - SP contaminated the local soil and, therefore, part of the population was intoxicated by the lead metal, detected by a hematologic exam conducted by the
Bauru's Municipal Health Department through Adolfo Lutz Institute (IAL/SES-SP). The result indicated the necessity of performing an investigation aiming to evaluate the developmental condition of all children from 0 to 12 years old living near the company.

Sixty seven contaminated children, from $3: 1$ to 6:11 years of age, who presented blood lead level above the value established as tolerable by the World Health Organization (10 g/dl), underwent speech-language screening, involving the speechlanguage screening protocol of the SpeechLanguage Department of USP/Bauru. Concerning the 67 children, 40 failed the screening and were called to be specifically evaluated. Of the 40 children called, twenty showed up to the language evaluation and constituted the sample of this study; twelve were male and eight were female, ranging in age from 3:1 to 6:11 years (mean age of 5:1 years). Children presented a blood lead level between 10,5 and 35,8 g/dl and were also submitted to a hearing evaluation that indicated normal hearing.

The children underwent language evaluation involving the following instruments:

1. Phonology Task from the ABFW - Child Language Test (13).

2. Vocabulary Task from the ABFW - Child Language Test (14).

3. Peabody Picture Vocabulary Tests, for the evaluation of receptive vocabulary (15).

4. Morphosyntax Evaluation Protocol (16). A 20 minutes language sample was recorded in video, and the following analysis criteria were used: type of sentence and of period used by the subjects; sentences extension and occurrence of verbal and nominal flexion deviances.

5. Pragmatic Skills Evaluation Protocol (16). A 20 minutes language sample was recorded in video and the following analysis criteria were used: total of verbal turns; total of non-verbal turns, number of times the child initiated the conversation turns, number of times the child answered and/or maintained the conversation topic, number of times the child used simple turns, number of times the child used expansive turns. The following communicative functions were listed: heuristic, naming, informative, narrative, protest, interactive.

The language evaluation was complemented with the following tasks:

1. Bucofacial and Articulation Praxis Protocol (17).

2. Hearing Immediate Memory, through the Hearing 
Sequential Memory of the Illinois Test of Psycholinguistic Abilities - ITPA(18).

These tasks were specifically selected once they involve important skills for the lexical acquisition, phonological reception and production.

The analysis of the pre-school children's performances was based on the scores obtained during the several language evaluation procedures, enabling the characterization of the subjects' language development as normal or altered.

A parental questionnaire was also applied, including closed and open questions about pregnancy, pre, peri and post natal intercurrences.

In order to investigate the existence of a correlation between the blood lead level and the language disorders presented by children, the Pearson Correlation Test was used (PACOTICO Program) and the significance level adopted was $5 \%$.

All procedures were carried out in the SpeechLanguage Clinic of the Bauru's Odontology Faculty of the University of São Paulo (FOB-USP).

\section{Results}

It is possible to observe in Table 1 the general performance presented by children for each linguistic skill evaluated. That is, the percentage of children who presented normal and altered performance in each linguistic subsystem evaluated, as well as in the complementary tasks.
Analyzing the individual performance, it was observed that 13 children (65\%) presented language disorder involving only the Phonology (phonological simplifications not expected for the age) or more than one linguistic subsystem (usually vocabulary and phonology alterations). Only one child did not present altered immediate hearing memory.

As mentioned before, children's parents were interviewed in order to gather information concerning the general development and health, especially those more relevant for the purpose of the study. Of the total of children surveyed $(n=$ 20 ), seven (35\%) presented a background that may affect language development, such as otitis $(n=2)$, prematurity $(\mathrm{n}=1)$, familiar history for language disorders $(n=2)$, birth intercurrences $(n=2)$. It's important to stress that all these children composed the group with language disorder.

Table 2 presents the distribution of children regarding the age, the lead level, other intercurrences (besides the lead) and the presence or not of language disorders.

A possible correlation between the blood lead level and the language disorder presented by children was also investigated. The Pearson Correlation Test showed that, in this case, there isn't a correlation between the studied variables. That is, the increase of lead concentration in blood did not determine a worse language performance $(\mathrm{r}$ $=0,0421$ e $\mathrm{p}=0,860)$.

TABLE 1. General performance of surveyed children for each skill tested.

\begin{tabular}{ccc}
\hline TASKS & NORMAL (\%) & ALTERED (\%) \\
Pragmatic Skills & 90 & 10 \\
Morfossintatic Organization & 90 & 10 \\
Expressive Vocabulary & 60 & 40 \\
Receptive Vocabulary & 25 & 75 \\
Phonology & 45 & 55 \\
Hearing Memory & 35 & 65 \\
Articulatory and Bucofacial Praxis & 100 & 0 \\
\hline
\end{tabular}


TABLE 2. Distribution of children regarding age (years: months), lead level (in $\mu \mathrm{g} / \mathrm{dl}$ ), intercurrences background and presence or not of language disorders.

\begin{tabular}{|c|c|c|c|c|}
\hline Subject & Age & Pb Level & Intercurrence & Language Disorder \\
\hline 1 & $5: 10$ & 14,0 & Present & Present \\
\hline 2 & $4: 9$ & 25,0 & Absent & Present \\
\hline 3 & $5: 10$ & 12,6 & Present & Present \\
\hline 4 & $4: 0$ & 16,1 & Absent & Present \\
\hline 5 & $6: 5$ & 18,0 & Absent & Present \\
\hline 6 & $3: 6$ & 19,0 & Absent & Present \\
\hline 7 & $4: 3$ & 16,0 & Absent & Present \\
\hline 8 & $5: 7$ & 23,0 & Present & Present \\
\hline 9 & $5: 1$ & 18,0 & Present & Present \\
\hline 10 & $6: 1$ & 11,6 & Present & Present \\
\hline 11 & $3: 10$ & 39,0 & Absent & Present \\
\hline 12 & $4: 4$ & 12,0 & Absent & Absent \\
\hline 13 & $6: 4$ & 17,9 & Absent & Absent \\
\hline 14 & 5:0 & 11,0 & Absent & Absent \\
\hline 15 & $5: 11$ & 16,8 & Present & Present \\
\hline 16 & $6: 6$ & 35,8 & Present & Present \\
\hline 17 & $5: 0$ & 10,0 & Absent & Absent \\
\hline 18 & $6: 2$ & 12,0 & Absent & Absent \\
\hline 19 & $6: 3$ & 10,5 & Absent & Absent \\
\hline 20 & $5: 10$ & 16,0 & Absent & Absent \\
\hline
\end{tabular}

\section{Discussion}

Despite many studies related to lead indicate general cognitive and language disorders in the contaminated population, the specialized literature did not yet reach a consensus regarding the neurotoxic effects of the metal.

In this study $65 \%$ of the contaminated children $(n=13)$ presented language disorders and three of them presented specifically phonological delay. The other 10 children presented delay in more than one linguistic system, especially the combination of phonology and vocabulary.
Concerning the vocabulary, a greater number of children presented worse performance in the receptive vocabulary task $(n=15)$ compared to the expressive one $(n=8)$. Despite knowing that the human being uses (expressive lexicon) a lower number of words than he is able to understand (receptive lexicon), this is not always verified by evaluation instruments. The reason for this is that the language evaluation through tests has a certain degree of artificiality, that is, many times the way we check a word comprehension depends on the 
child's understanding o what we want. In the Peabody test, the receptive vocabulary is verified through the choosing of a picture within 4 that represent the word said by the examiner. Frequently, we observe that the subject, especially children, does not seem to truly understand what we're asking, making the comprehension evaluation more difficult than the expression one, because of the number of variables involved. Anyway, considering the purposes of this study of the 15 children who presented deficit in the Peabody test, only 10 were classified as having language disorder by presenting difficulties in other tasks besides this one.

As described in the introduction, several studies have found developmental disorders in children, including language disorders, caused by the lead exposure specially in cases where the blood metal concentration is above the tolerable value, of $10 \mathrm{~g} / \mathrm{dl}(1,5,6)$. Despite not finding a significant correlation between the contamination level and the language development, this study points out that the contamination by lead can constitute a risk factor for language development disorders for the studied children. As well as in other studies, that wasn't possible to make such correlation (10-11), the authors pointed to the influence that the lead contamination may have upon children's development.

On the other hand, many other studies found a correlation between the lead level and the performance in cognitive tasks, including language tasks, considering varied ages $(1,-2,4-7)$. When comparing the linguistic performance of children with higher and lower metal level, showed that those with higher lead level presented worse performance, evidencing the substance's effects in the child's neurodevelopment. One of these studies, verified the presence of inverse association between lead concentration and the performance of preschool children in tests of Central Auditory Processing, even controlling the environmental factors (4).

Other factors besides the neurotoxic agents may lead to nervous system damages, and consequently in children's development, such as genetic factors and the several pre, peri and post natal intercurrences. In this sense, this study has also searched to collect data regarding these other aspects through parental interviews.

Of the 20 children surveyed, 7 (35\%) presented intercurrences that may affect children's development, including language development. It's worth to stress that all 7 children belonged to the group with linguistic disorders. These findings remit us to the statements that genetic and environmental factors may aggravate the hindering effects of lead in the neural development, making some children more vulnerable to its neurotoxic effects (12).

Concerning specifically the environmental aspect, it's important to mention that children of this study belong to a lower socio-cultural level, which can be a risk factor for the delay observed in their language development. This data, in association with the others presented, doesn't permit to attribute the language disorder found only to the neurotoxic effects of lead. As mentioned previously, despite the lead has a significant influence in children's development, the existente of other environmental factors - such as the environment where children live, the cultural and schooling level of parents and the quality of schools - may be even stronger $(10,12)$.

Another finding that should be considered when discussing language is the percentage of children presenting disorder in the short term memory task. Specifically in the immediate hearing memory, 13 subjects $(55 \%)$ presented limited memorizing skills. Yet, 12 of those 13 children presented disorder in one or more linguistic systems, suggesting a relation between language difficulties and memory. It is known that in cases of children with Specific Language Impairment (who are usually delayed concerning vocabulary knowledge and/or other language subsystems besides comprehension), one of the hypothesis for some of the language difficulties observed refer to a memory system with limited capacity, emphasizing the phonological and lexical disorders. This relation could be related to the proximity between the memory disorder levels, phonology and expressive vocabulary $(75 \%, 65 \%$ e $55 \%)$.

When considering memory, we also have to consider a cognitive function tightly related to language, negatively affected by the lead intoxication, as well as other cognitive functions, even when it is below $10 \mathrm{~g} / \mathrm{dl}(3,8,9)$. The findings of the present study agree with the ones mentioned above, once it was found a considerable amount of damage in this function.

Despite this study have focus on 20 children who came for specific evaluation, it's necessary to stress that of the 67 children initially screened, 40 failed speech-language screening. These results, as well as others found in the literature, suggest and reinforce the need to face the problem of lead exposure as one of the many risk factors that interfere in children's neurodevelopment. 


\section{Conclusion}

This study did not find a correlation between the severity of language impairment and the lead level presented by pre-school children. On the other hand, the occurrence of $13(65 \%)$ children with language impairment indicates that the metal contamination is a risk factor for the disorders found, even when other factors that may lead to language development delay were observed.

\section{References}

1. Wasserman GA, Graziano JH, Factor-Litvak P, Popovac D, Morina N, Musabegovic A. Consequences of lead exposure and iron supplementation on childhood development at age 4 years. Neurotoxicol Teratol. 1993 May-Jun;16(3):233-40.

2. Schnaas L, Rothenberg SJ, Perroni E, Hernández RM, Hernandez C, Martinez S. Relación entre la exposición prenatal y postnatal al plomo y el desarrollo intelectual del niño a los 42 meses de edad. Perinatol Reprod Hum. 1999;13(3): 214-20.

3. Lanphear BP, Dietrich K, Auinger P, Cox C. Cognitive deficits associated with blood lead concentrations $<10 \mathrm{mg} /$ dl in US children and adolescents. Public Health Rep. 2000 nov-dec;115(6):521-29.

4. Dietrich KN, Succop PA, Berger OG, Keith RW. Lead exposure and the central auditory processing abilities and cognitive development of urban children: the cincinnati lead study cohort at age 5 years. Neurotoxicol Teratol. 1992 janfeb;14(1):51-6.

5. Campbéll TF, Needleman HL, Riess JA, Tobin MJ. Bone lead levels and language processing performance. Dev Neuropsychol. 2000;18(2):171-86.

6. Bellinger DC, Hu H, Kalaniti K, Thomas N, Rajan P, Sambandam S, et al. A pilot study of blood lead levels and neurobehavioral function in children living in Chennai, India. Int J Occup Environ Health. 2005 apr-jun;11(2):13843.

7. Wang CL, Chuang HY, Ho CK, Yang CY, Tsai JL, Wu TS, et al. Relationship between blood lead concentrations and learning achievement among primary school children in Taiwan. Environ Res. 2002 may;89(1):12-8.

8. Kordas K, Canfield RL, López P, Rosado JL, Vargas GG, Cebrián ME, et al. Deficits in cognitive function and achievement in Mexican first-graders with low blood lead concentrations. Environ Res. 2006 mar;100(3):371-86.

9. Tellez-Rojo MM, Bellinger DC, Arroyo-Quiroz C, Lamadrid-Figueroa H, Mercado-Garcia A, Schnaas-Arrieta $\mathrm{L}$, et al. Longitudinal associations between blood lead concentrations lower than $10 \mathrm{microg} / \mathrm{dL}$ and neurobehavioral development in environmentally exposed children in Mexico City. Pediatrics. 2006 aug;118(2):323-30.
10. Wasserman GA, Liu X, Lolacono NJ, Factor-Litvac P, Kline JK, Popovac D. Lead exposure and intelligence in 7year-old children: the yugoslavia prospective study. Environ Health Perspect. 1997 sep;105(9):956-61.

11. Prpic-Majic D, Bobicc J, Simicc D, House DE, Otto DA, Jurasovicc J, et al. Lead absorption and psychological function in Zagreb (Croatia) school children. Neurotoxicol Teratol. 2000 may-jun;22(3):347-56.

12. Lidsky TI, Schneider JS. Lead neurotoxicity in children: basic mechanisms and clinical correlates. Brain. 2003 jan;126(pt.1):5-19.

13. Wertzner HF. Fonologia. In: Andrade CRF, Béfi-Lopes DM, Fernandes FDM, Wertzner HF. ABFW: Teste de linguagem infantil nas áreas de fonologia, vocabulário, fluência e pragmática. $2^{\mathrm{a}}$ ed. Barueri: Pró-Fono; 2004. 140 .

14. Béfi-Lopes DM. Vocabulario. In: Andrade CRF, BéfiLopes DM, Fernandes FDM, Wertzner HF. ABFW: Teste de linguagem infantil nas áreas de fonologia, vocabulário, fluência e pragmática. $2^{\mathrm{a}}$ ed. Barueri: Pró-Fono; 2004. 41-59.

15. Capovilla FC, Capovilla AGS. Desenvolvimento lingüístico na criança Brasileira dos dois aos seis anos: tradução e estandardização do Peabody Picture Vocabulary Test de Dunn \& Dunn e da Language Development Survey de Rescorla. Ciência Cognitiva: teoria, pesquisa e aplicação. 1997 jan-jun;1(1):353-80.

16. Hage SRV. Protocolo de anamnese e avaliação fonoaudiológica. Bauru; 2000. 27 p.

17. Hage SRV. Dispraxia Articulatória: Correlações Com o Desenvolvimento da Linguagem. In: Marchesan I, Zorzi J. Anuário CEFAC de Fonoaudiologia. $1^{\mathrm{a}}$ ed. Rio de Janeiro: Revinter; 1999. p. 119-30.

18. Bogossian MA, Santos MJ. Adaptação Brasileira (edição revisada) Teste Illinois de Habilidades Psicolingüísticas. Rio de Janeiro: EMPSI - Empr. Psicologia Ltda; 1977. 